\title{
Comparative morphology of parenchymal cells in Acoelomorpha and Plathelminthes
}

\author{
G.R. Gazizova, Ya.I. Zabotin, A.I. Golubev \\ Kazan Federal University, Kremlevskaya str., 18, Kazan, 420008 Russia. E-mails: grgazizova \\ @gmail.comyaroslav_zabotin@rambler.ru anatolii.golubev_1937@mail.ru
}

ABSTRACT: Parenchyma is one of the important morphofunctional features of the organization of Acoela and Plathelminthes. It plays a main role in many physiological processes of their organism such as digestion and excretion, regulatory processes, transport as well as their wonderful ability to regeneration. The study of its nature and development is important for understanding of these processes as well as for obtaining data on morphology, phylogenetics and evolution of this significant group of metazoans. According to this aim, we have carried out a comparative morphological research of parenchyma in 1 species of acoel and 10 species of flatworms, including free-living ones, fluke and tapeworm, on ultrastructural level. As a result of analysis of ultrastructural organization of these species' parenchyma the morphofunctional classification of cells is proposed. We distinguish seven cell types differing by the structure and certain functions. The parenchyma of each species examined is characterized by a unique combination of these cell types. Occurrence of the similar parenchymal cell morphotypes in representatives of Acoela and phylogenetically distant groups of flatworms, to our opinion, allows considering the specialization of this tissue as a parallel evolution.

How to cite this article: Gazizova G.R., Zabotin Ya.I., Golubev A.I. 2017. Comparative morphology of parenchymal cells in Acoelomorpha and Plathelminthes // Invert. Zool. Vol.14. No.1. P.21-26. doi: 10.15298/invertzool.14.1.04

KEY WORDS: parenchyma, flatworms, Plathelminthes, Acoela, morphofunctional classification, ultrastructure.

\section{Сравнительная морфология клеток паренхимы Acoelomorpha и Plathelminthes}

\author{
Г.Р. Газизова, Я.И. Заботин, А.И. Голубев
}

Казанский федеральный университет, ул. Кремлевская, 18, Казань, 420008 Pоссия. E-mails: grgazizova@gmail.com yaroslav_zabotin@rambler.ru anatolii.golubev_1937@mail.ru

РЕЗЮМЕ: Паренхима является одной из важных морфофункциональных особенностей организации Acoela и Plathelminthes. Она играет ключевую роль во многих физиологических процессах их организма, таких как пищеварение и выделение, регулятивных процессах, транспорте веществ, а также участвует в регенерации. Исследование ее природы и развития важно для понимания этих процессов, а также для получения данных по морфологии, филогенетике и эволюции многоклеточных. В связи с этой целью проведено сравнительно-морфологическое исследование паренхимы у 1 вида Acoela и 10 видов плоских червей, включая свободноживущих и 
паразитических, на ультраструктурном уровне. В результате анализа ультраструктурной организации паренхимы этих видов предложена морфофункциональная классификация клеток. Выделено семь типов клеток, различающихся по структуре и выполняемым функциям. Паренхима каждого исследованного вида характеризуется уникальной комбинацией этих типов клеток. Возникновение подобных морфотипов клеток паренхимы у представителей Acoela и филогенетически отдаленных групп плоских червей, на наш взгляд, позволяет рассматривать специализацию этой ткани как параллельную эволюцию.

Как цитировать эту статью: Gazizova G.R., Zabotin Ya.I., Golubev A.I. 2017. Comparative morphology of parenchymal cells in Acoelomorpha and Plathelminthes // Invert. Zool. Vol.14. No.1. P.21-26. doi: 10.15298/invertzool.14.1.04

КЛЮЧЕВЫЕ СЛОВА: паренхима, плоские черви, Plathelminthes, Acoela, морфофункциональная классификация, ультраструктура.

\section{Introduction}

The evolutionary-morphological study of Plathelminthes plays the key role for the solving the problem of origin of various tissues and organ systems in bilaterian animals. Previously this phylum also included the Acoelomorpha, the invertebrate group with the debatable phylogenetic position, despite according to the modern molecular data, they are considered to be the independent lineage of basal bilaterians (RuizTrillo et al., 1999; Cannon et al., 2016). One of the notable features of the organization in both these taxa is the parenchyma - a special type of tissue that fills the space of their body between the body-wall muscles and internal organs. It is defined as a complex system of cells and extracellular structures, performing a variety of functions for the maintenance of the internal environment. The study of the morphology of the parenchyma is an important step in understanding the biology and physiology of Acoelomorpha and flatworms.

Despite many years of studying the morphology of the parenchyma of certain species of flatworms (as well as Acoelomorpha) at the light-optical and the ultrastructural levels, there is still no consensus about its nature, functional and phylogenetic significance. Some zoologists considered parenchyma a primitive feature of their organization (Beklemishev, 1964; Ivanov, Mamkaev, 1973), while the others believed it to be a secondary simplified connective tissue (Malakhov, 2009). The cellular composition of the parenchyma is also uncertain. Some researchers, based on a topographical point of view, refer to parenchyma all cells that occupy the space between the body-wall muscles and internal organs of flatworms, thus giving it the status of the structure of the organ level (Rieger, 1981). From the alternative, histological point of view, parenchyma is often considered a type of connective tissue which is composed of separate certain cells or syncytium and extracellular matrix (Kornakova, 1989; Goryshina, Chaga, 1990).

The aim of the present work is expanding the knowledge about organization, evolutionary and phylogenetic patterns of development of parenchyma, based on electron microscopic morphological data from 1 species of Acoela and 10 species of Plathelminthes. In this study, we define parenchyma as a complex of cells and intercellular matrix which is located in the space between the body-wall muscles and the intestine, with the exception of germ cells, nerve cells, cytons (the insunk nuclear parts of the epidermal cells), cyrtocytes and muscle cells.

\section{Materials and methods}

Representatives of an acoel Convoluta convoluta (Abildgaard, 1806) (Acoelomorpha, Acoela), free-living flatworms Monocelis lin- 
eata (Müller O.F., 1773) (Proseriata), Uteriporus vulgaris Bergendal, 1890 (Tricladida, Maricola), Provortex karlingi Ax, 1951 (Rhabdocoela, Dalytyphloplanoida) and Macrorhynchus croceus (Fabricius, 1826) (Rhabdocoela, Kalyptorhynchia) were collected on the littoral of Keretskii archipelago (Chupa Bay) of White Sea; Geocentrophora intersticialis Timoshkin, 1984 (Lecithoepitheliata), Baikalobia guttata (Gerstfeldt, 1858) and Microarchicotylus stringulatus (Korotneff, 1912) (Tricladida, Continenticola) - in interstitial zone and littoral of Lake Baikal (Bolshie Koty); Dendrocoelum lacteum Ørsted, 1844 (Tricladida, Continenticola) - on littoral of Lake Goluboe (Tatarstan, Russia). Rediae and cercariae of the fluke $\mathrm{Hi}$ mastla elongata (Mehlis, 1831) (Trematoda) were collected from liver of a White Sea gastropod Littorina saxatilis (Olivi, 1792). Representatives of a tapeworm Eubothrium sp. Nybelin, 1922 (Cestoda) were collected from intestine of a White Sea codfish Gadus morhua marisalbi Derjugin, 1920 (taxonomy of acoels and freeliving flatworms after Tyler et al., 2006-2016). Worms were fixated in $1 \%$ glutaraldehyde on $0.1 \mathrm{M}$ phosphate buffer ( $\mathrm{pH} 7.4$ ), then were postfixated in $1 \%$ OsO4 solution on the same phosphate buffer. The material was dehydrated in an alcohol series of ascending concentrations and acetone, and then was embedded in epon resin. Ultrafine sections were obtained using ultratome "Rheichert" (Austria). Sections were placed on metal grids and then stained with uranyl acetate $\left(50 \mathrm{~min}\right.$ at $\left.60^{\circ} \mathrm{C}\right)$ and lead citrate according to Reynolds methodic (Reynolds, 1963). Ultrafine sections were examined and photographed by a transmission electron microscope Jeol JEM-100 CX II (Japan).

\section{Results}

Since in the previous study we described ultrastructure of parenchymal cells in one species of Acoela and 5 species of free-living flatworms (Gazizova et al., 2013), here we complement the research of flatworms parenchyma by data of three species of triclads and two species of neodermates.
In the planarian Baikalobia guttata the four types of parenchymal cells were found. The first type is large cells with electron-dense cytoplasm. They have a variety of shapes, most often form elongate processes. Their cytoplasm is densely filled with EPR, several lipid drops occur. The second cell type is characterized by containing less electron-dense cytoplasm and a smaller number of EPR channels. The third type of cells is characterized by the presence of thin, vacuolated processes and the electron-transparent cytoplasm. The organelles are tightly concentrated in the perikaryon of the cell. And the fourth type is distinguished by the small size, high nuclear-cytoplasmic ratio and less amount of organelles in cytoplasm.

In the second planarian species Microarchicotylus stringulatus three types of parenchymal cells were found, similar to the structure of I-III cell types in B. guttata. The first type of cells is characterized by wide channels of granular EPR and electron transparent vacuoles filled with fine-fibrous contents reminiscent of the surrounding extracellular matrix. The cytoplasm of II type cells contains fine channels of granular EPR, as well as a large number of mitochondria forming clusters. The III type of cells is distinguished by electron transparent hyaloplasm, dense lipid droplets and forming long processes.

In general, the parenchyma of the marine triclad Uteriporus vulgaris is similar in its structure to the above-described freshwater triclads, but it has some differences in the morphology of cells. Four types of parenchymal cells are distinguished. The first type cells are filled by large number of EPR channels and contain an electron transparent hyaloplasm and round electron-dense granules. II type cells have an elongated shape and are characterized by the presence of large mitochondria with an electron transparent matrix and rare cristae, as well as the small elongated electron dense granules. The most numerous are III type cells. They are distinguished by the presence of long processes and vacuolated electron transparent cytoplasm. In $U$. vulgaris the parenchymal cells capable of phagocytosis were found. They are similar to the third type of cells, but they contain phago- 
somes filled with "digested" remnants of other cells in their cytoplasm.

In rediae of the fluke Himastla elongata we found one type of parenchymal cells, characterized by formation of the long processes which paves a cavity with maturing cercariae. They contain electron transparent cytoplasm filled by fine-fibrous material and rare lipid drops. In cercariae the two types of parenchymal cells are distinguished. The first type of cells has electron transparent cytoplasm and elongate processes filled with large lipid drops. The second type of parenchymal cells is characterized by high nuclear-cytoplasmic ratio and electron dense cytoplasm.

In parenchyma of tapeworm Eubothrium sp. we found only one type of cells characterized by formation of long processes and the presence of a large amount of glycogen granules. One of the main features of parenchyma in parasitic classes of flatworms is that processes of parenchymal cells participate in formation of specific cavities, which assume the supporting function.

\section{Discussion}

The parenchyma of Acoela and flatworms is represented by the variety of cellular types and construction variants. The highest variability of parenchymal cells is found in acoel Convoluta convoluta (five different types in peripheral zone and one type in central zone of parenchyma) and in Geocentrophora intersticialis (6 types of cells) (Gazizova et al., 2013).

During the evolution of parenchyma within flatworms the two parallel processes are observed: on the one hand, a decrease of the cellular diversity, and on the other, an intensification of the morphofunctional specialization of cells and their topographical affinity. According to our data, the similar level of cellular diversity of the parenchyma is demonstrated by the basal neoophoran proseriate Monocelis lineata (four cell types) and the representatives of the derived flatworm order triclads Uteriporus vulgaris, Baikalobia guttata (also four cell types), Dendrocoelum lacteum and Microarchicotylus stringulatus (three cell types). The dalytyphloplanoid rhabdocoel Provortex kar- lingi also possesses three types of parenchymal cells, while in the Macrorhynchus croceus (a member of specialized order Kalyptorhynchia) only two cell types are described.

Finally, in the evolutionary direction leading to the neodermates, the number of parenchymal cell types reduces and its volume decreases. Remarkably, the parenchyma of larval stages of trematodes and cestodes consists of only one type of cells (Bonsdorff et al., 1971; Dobrovolsky et al., 1983), which indicates the cytomorphological specialization of Neodermata in the earliest stages of ontogeny. In rediae of Himastla elongata we found one type of parenchymal cells, characterized by long processes paved a cavity where the next parthenogenetic generation matures. Whereas cercariae have two types of cells suggested as parenchymal. In the most specialized parasites, the cestodes, the parenchyma undergoes the stronger reduction. According to our research, in the parenchyma of pseudophyllidean cestode Eubothrium sp. only one type of cells is found, characterized by a large amount of glycogen and elongate processes. While in the basal bilaterians Acoela and in the most free-living taxa of flatworms the principle of the archaic morphological diversity works (Mamkaev, 1991), the neodermates, on the contrary, tend to universalize the structure of this type of tissue.

There are several classifications of parenchymal cells of Plathelminthes. Rieger (1981) identifies three classes of cells in the parenchyma: immersed bodies of glandular cells of the epidermis, pharynx or genital organs, stem cells (neoblasts or replacement cells) and fixed parenchymal cells. An alternate classification is proposed by Conn (1993), who distinguishes three types of cells: myocytes, neoblasts and the variable specialized cells. The latter category includes fixed parenchymal, pigment and "chordoid" cells of free-living flatworms, as well as calcareous cells of cestodes. The classification of parenchymal cells suggested by Pedersen (1983) varies for different orders of flatworms; however, he usually distinguishes only two types of cells: neoblasts and fixed parenchymal cells. Our observations of the fine structure of the parenchyma in Acoela and flatworms from dif- 


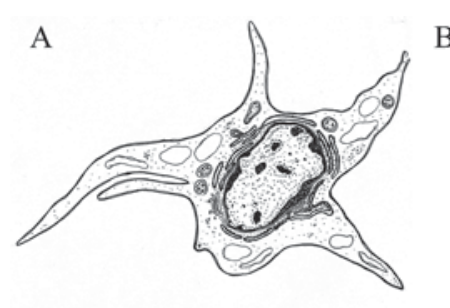

D

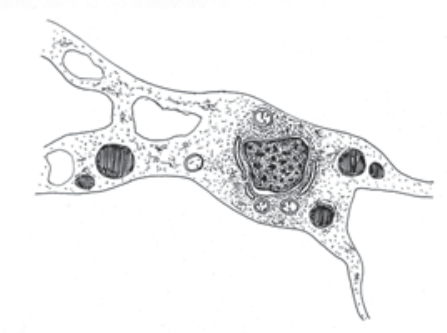

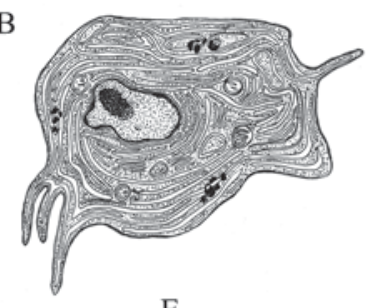

E
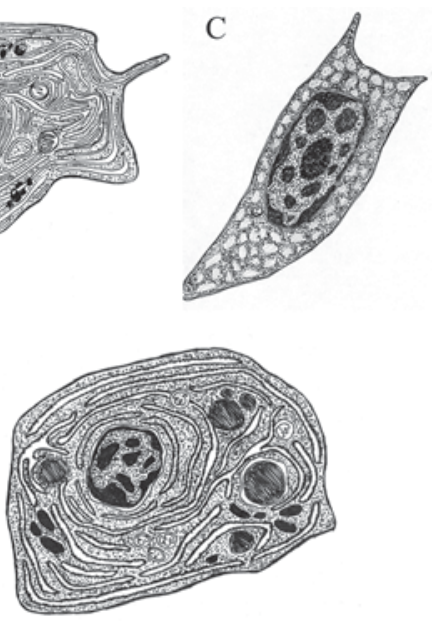
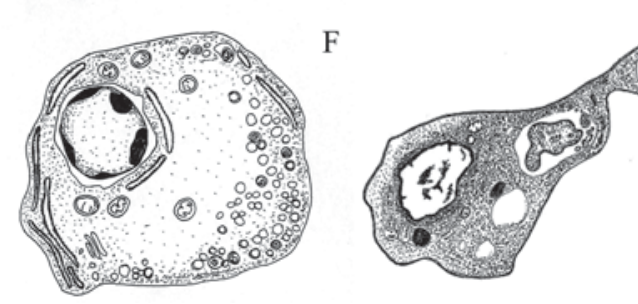

G

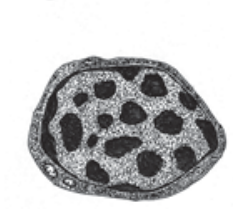

Fig. 1. Morphofunctional classification of parenchymal cells in Acoela and flatworms. A — supporting cells; B - secretory cells; C — reserve (storage) cells; D — reserve-supporting cells; E — reserve-secretory cells; $\mathrm{F}$ - digestive (phagocytic) cells; $\mathrm{G}$ — neoblasts or non-differentiated cells.

Рис. 1. Морфофункциональная классификация клеток паренхимы Acoela и плоских червей. A опорные клетки; В - секреторные клетки; C - резервные (запасающие) клетки; D - опорнозапасающие клетки; E - секреторно-запасающие клетки; F — пищеварительные (фагоцитарные) клетки; G - необласты или малодифференцированные клетки.

ferent orders allow the distinguishing the following types of cells similar in structure and performing analogical functions (Fig. 1).

A. Supporting cells. They have processes of various lengths. The small amount of organelles is located in the electron transparent cytoplasm. The numerous large vacuoles representing the hydrostatic skeleton are found (Fig. 1A). This is the most common type of cells, which forms the main content of parenchyma. It includes II type and IV type cells of $C$. convoluta, II type of $M$. lineata, II and III types of D. lacteum, B. guttata and $U$. vulgaris.

B. Secretory cells. The cytoplasm is electron dense, rich in secretory granules. The rest of the cell volume is literally filled with wide channels of granular EPR, numerous dictyosomes of the Golgi complex and free ribosomes (V type cells of the C. convoluta, I and VI types of G. intersticialis, I type of Mac. croceus and Mic. stringulatus) (Fig. 1B).

C. Reserve (storage) cells. The large lipid droplets and numerous glycogen granules are present in the cell cytoplasm (II type cells of $G$. intersticialis) (Fig. 1C).

D. Reserve-supporting cells. They have processes of various lengths and contain electron transparent vacuoles with hydrostatic function, and reserve lipid droplets (I type cells of $C$. convoluta, M. lineata and $P$. karlingi, III type of cells of Mic. stringulatus, parenchymal cells of H. elongata and Eubothrium sp.) (Fig. 1D). 
The presence of cells combining both of these functions, in our opinion, is additional evidence in still weak cell differentiation of this type of tissue in flatworms.

E. Reserve-secretory cells. They combine reserve inclusions (lipid droplets) and secretory granules (IV type cells of $G$. intersticialis, IV type of $M$. lineata, I type of $D$. lacteum, $B$. guttata and $U$. vulgaris, II type of $P$. karlingi) in the cytoplasm (Fig. 1E).

F. Digestive (phagocytic) cells were observed in central parenchyma of acoel C. convoluta and in triclad $U$. vulgaris (IV type). They often contain numerous digestive vacuoles, scattered organelles and cellular derivatives (Fig. $1 \mathrm{~F})$.

G. Neoblasts or non-differentiated cells. They are relatively rare. They are characterized by small size, high nuclear-cytoplasmic ratio and a small amount of organelles (Fig. 1G). Neoblasts are found in G. intersticialis (V type), M. lineata (type III), B. guttata (IV type), Mac. croceus (type II) and in cercariae of H. elongata (II type).

We are far from the idea that the cellular variety of the parenchyma of the Acoela and flatworms is limited only by the outlined list. Proposing this classification, we aim to emphasize the various ways of solving the evolutionary problems that are performed by this type of tissue. The presence of similar types of parenchyma cells in representatives of phylogenetically distant groups of Plathelminthes, as well as in Acoela, to our opinion, allows us to consider this trend as a parallel evolution. The obtained results indicate a tendency to morphofunctional specialization of cells in flatworms. In our opinion, the degree of differentiation of the parenchyma and its integration with other types of tissues can be considered as a criterion of progressive evolution.

\section{References}

Beklemishev V.N. 1964. [Basics of comparative anatomy of invertebrates]. 3rd ed. Vol.2. Moscow: Nauka. 446 p. [In Russian].
Bonsdorff C.H., Forrsten I., Gustafsson M., Wikgren B.J. 1971. Cellular composition of procercoids of Diphyllobothrium dendriticum (Cestoda) // Acta zool. fenn. Vol.132. P.1-25.

Cannon J.T., Vellutini B.C., Smith III J., Ronquist F., Jondelius U., Hejnol A. 2016. Xenacoelomorpha is the sister group to Nephrozoa // Nature. Vol.530. P.89-93.

Conn D.B. 1993. The biology of flatworms (Platyhelminthes): Parenchyma cells and extracellular matrices // Trans. Amer. Microsc. Soc. Vol.112. No.4. P.241261.

Dobrovolsky A.A., Galaktionov K.V., Mukhammedov G.K., Sinkha B.K., Tikhomirov I.A. 1983. [Parthenogenetic generations of trematodes] // Tr. Leningradsk. ob-va estestvoispyt. Vol.82. No.4. 107 p. [in Russian].

Gazizova G.R., Zabotin Ya.I., Malutina L.V., Golubev A.I. 2013. [The structure of the parenchyma of turbellarians in the ultrastructural and phylogenetic aspects] //Uchen. zap. Kazan. univ. Ser. Estestv. nauki Vol.155. No.3. P.99-115 [in Russian, with English summary]. Goryshina E.N., Chaga O.Yu. 1990. [Comparative histology of internal tissues with the basics of immunology]. Leningrad: LGU. 320 p. [In Russian].

Ivanov A.V., Mamkaev Yu.V. 1973. [Ciliated worms (Turbellaria), their origin and evolution]. Phylogenetic essays. Leningrad: Nauka. 221 p. [In Russian].

Kornakova E.E. 1989. [The structure of the parenchyma of Udonella murmanica (Turbellaria, Udonellida) and the main trends in the evolution of connective tissue of flatworms] // Parasitol. sb. Zool. Inst. AN SSSR. Vol.36. P.161-179 [in Russian].

Malakhov V.V. 2009. [The revolution in zoology: a new system of bilateria] // Priroda. Vol.3. P.40-54 [in Russian].

Mamkaev Yu.V. 1991. [On the morphological basis of system of the flatworms] // Tr. Zool. Inst. AN SSSR. Vol.241. P.3-25 [in Russian].

Pedersen K.J. 1983. Fine structural observations on the turbellarians Stenostomum sp. and Microstomum lineare with special reference to the extracellular matrix and connective tissue systems // Acta Zool. (Stockh.). Vol.64. No.4. P.177-190.

Ruiz-Trillo I., Riutort M., Littlewood D., Herniou E., Baguna J. 1999. Acoel flatworms: earliest extant bilaterian metazoans, not members of Platyhelminthes // Science. Vol.283. P.1919-1923.

Rieger R.M. 1981. Morphology of the Turbellaria at the ultrastructural level // Hydrobiologia. Vol.84. P.213229.

Reynolds E.S. 1963. The use of lead citrate at high $\mathrm{pH}$ as an electron opaque stain in electron microscopy // J. Cell Biol. Vol.17. P.208-212.

Tyler S., Schilling S., Hooge M., Bush L.F. 2006-2016. Turbellarian taxonomic database. Version 1.7. http:// turbellaria.umaine.edu.

Responsible editor E.N. Temereva 